\title{
Resolving the Problem of Compliance with the Ever Increasing and Changing Regulations

\section{DISCLAIMER}

This report was prepared as an account of work sponsored by an agency of the United States Government. Neither the United States Government nor any agency thereof, nor any of their employees, makes any warranty, express or implied, or assumes any legal liability or responsibility for the accuracy, completeness, or usefulness of any information, apparatus, product, or process disclosed, or represents that its use would not infringe privately owned rights. Reference herein to any specific commercial product, process, or service by trade name, trademark, manufacturer, or otherwise does not necessarily constitute or imply its endorsement, recommendation, or favoring by the United States Government or any agency thereof. The views and opinions of authors expressed herein do not necessarily state or reflect those of the United States Government or any agency thereof.

\section{Prepared for the U.S. Department of Energy Assistant Secretary for Nuclear Energy}

\author{
(29) Westinghouse \\ Hanford Company Richland, Washington \\ Hanford Operations and Engineering Contractor for the \\ U.S. Department of Energy under Coniract DE-AC06-87RL10930
}

Copyright License By acceptance of this article, the publisher and/or recipient acknowledges the U.S. Covernment's right to relain a nonexclusive, royalfy-tree license in and lo any copyright covering this paper. 


\section{DISCLAIMER}

This report was prepared as an account of work sponsored by an agency of the United States Government. Neither the United States Government nor any agency Thereof, nor any of their employees, makes any warranty, express or implied, or assumes any legal liability or responsibility for the accuracy, completeness, or usefulness of any information, apparatus, product, or process disclosed, or represents that its use would not infringe privately owned rights. Reference herein to any specific commercial product, process, or service by trade name, trademark, manufacturer, or otherwise does not necessarily constitute or imply its endorsement, recommendation, or favoring by the United States Government or any agency thereof. The views and opinions of authors expressed herein do not necessarily state or reflect those of the United States Government or any agency thereof. 


\section{DISCLAIMER}

Portions of this document may be illegible in electronic image products. Images are produced from the best available original document. 
LEGAL DISCLAIMER

This report was prepared as an account of work sponsored by an agency of the United States Government. Nelther the Uniled States Government nor any agency thereof, nor any of their employoes, nor any of thoir conlraclors, subcontractors or their employees, makos any warranty, oxpress or impliod, or assumes any logal liability or responsibility for the accuracy, completeness, or any third party's use or the results of such use of any inlormation, apparatus, producl, or procoss disclosed, or represonts that its use would not infringe privately owned rights. Relerence herein to any spocilic commercial producl, process, or service by Irade name. trademark, manulacturer, or otherwise, does nol necessarily constitute or imply its endorsement, recommendation, or favoring by the United States Government or any agency thereol or its contractors or subcontractors. The views and opinions ol authors expressed herein do nol necessarily slate or rellect those of the United Slates Government or any agency thereol.

This report has been reproduced from the best available copy.

Prinled in the Uniled Stales of America

DISCLM-2.CHP (1.91) 


\section{Resolving the Problem of Compliance with the Ever Increasing and Changing Regulations}

H. Leigh

Westinghouse Hanford Company

Date Published

June 1991

To Be Presented at

University of New Mexico

9th Symposium on Space Nuclear Power

Albuquerque, New Mexico

January 12-16, 1992

Prepared for the U.S. Department of Energy Assistant Secretary for Nuclear Energy

(2) Westinghouse Hantord Company Richland, Washington 99352

Hanford Operations and Engineering Contractor for the

U.S. Department of Energy under Contract DE-AC06-87RL10930

Copyright License By acceptance of this article, the publisher and/or recipient acknowledges the U.S. Government's right to relain a nonexclusive, royally-tree license in and to any copyright covering this paper. 


\title{
RESOLVING THE PROBLEM OF COMPLIANCE WITH THE EVER INCREASING AND CHANGING REGULATIONS
}

\author{
Harley Leigh \\ Westinghouse Hanford Company \\ P.0. Box 1970, Mailstop N1-41 \\ Richland, WA 99352
}

(509) $376-2972$

\begin{abstract}
The most common problem identified at several U.S. Department of Energy (DOE) sites is regulatory compliance. Simply, the project viability depends on identifying regulatory requirements at the beginning of a specific project to avoid possible delays and cost overruns.

The Radioisotope Power Systems Facility (RPSF) is using the Regulatory Compliance System (RCS) to deal with the problem that well over 1,000 regulatory documents had to be reviewed for possible compliance requirements applicable to the facility. This overwhelming number of possible documents is not atypical of all DOE facilities thus far reviewed using the RCS system.

The RCS was developed to provide control and tracking of all the regulatory and institutional requirements on a given project. WASTREN, Inc., developed the RCS through various DOE contracts and continues to enhance and update the system for existing and new contracts. The RCS provides the information to allow the technical expert to assimilate and manage accurate resource information, compile the necessary checklists, and document that the project or facility fulfills all of the appropriate regulatory requirements. The RCS provides on-line information, including status throughout the project 1 ife, thereby allowing more intelligent and proactive decision making. Also, consistency and traceability are provided for regulatory compliance documentation.
\end{abstract}

\section{INTRODUCTION}

A11 nuclear facilities are required by DOE Order 5480.5, Safety of Nuclear Facilities (DOE 1986), to perform a readiness review on all new facilities and most facilities that require a restart. To be successful, these reviews require an assessment of the state of regulatory compliance. How is this task accomplished on complex projects like the RPSF? The list of potentially applicable regulatory documents exceeds 1,200 . The number of requirements invoked by approximately 400 applicable documents is tens of thousands.

Currently there has been a change regarding what represents full compliance with federal regulations, DOE Orders, and requirements of other federal and state agencies. In the past, detailed reviews by experts in their specific fields of expertise would review for compliance and provide a statement that the document, procedure, system, facility, or process equipment was in compliance with the requirements. For today and future projects, only the line-by-1ine documentation of the specific requirements and how those 
requirements are met is the acceptable and successful approach. This is particularly true where fines and/or jail sentences may be invoked by 1 aw for noncompliance, even if inadvertent or unintentional.

One of the major problems in assessing regulatory compliance is not knowing all of the requirements of a specific operation or project. This problem is further compounded by the rapid changing of and additions to regulatory and institutional requirements. The next major consideration is how to accomplish the task of regulatory compliance to maintain startup schedules in a cost effective and timely manner.

The RPSF is located in the Fuels and Materials Examination Facility (FMEF) at the DOE Hanford Site in southeastern Washington State. The FMEF, completed in 1984, was designed and constructed as a Seismic Class I facility to be used for the examination of nuclear fuels and materials. As the DOE missions have evolved, so has the purpose of the FMEF. It is a building well-suited for RPSF purposes because it meets the environmental and safety requirements of a nuclear facility and currently is being modified to provide for the assembly of Radioisotope Thermoelectric Generators (RTG). The assembly process is based on one developed at Mound Laboratory [operated by EG\&G Mound Applied Technologies Inc. (Mound)] on the DOE Mound Site in Miamisburg, Ohio. Westinghouse Hanford Company (Westinghouse Hanford) is designing and constructing the facility to ensure the heat source assemblies are produced in a manner that is in complete compliance with today's regulatory and institutional requirements.

\section{SYSTEM METHODOLOGY}

Although the RCS is being used for many different reviews or assessments, establishing regulatory requirements, and conducting operational readiness reviews (ORR), the system methodology is fairly constant. An RCS ORR flow chart (Figure 1) illustrates the interface between the activities performed in demonstrating and documenting facility readiness.

The initial phase, "Analysis," includes the preparation of a requirements document, a critical systems document, a compliance decision tree, and a review plan.

The requirements document contains the results of applicability assessment from a list of potentially applicable regulatory and institutional documents. Specific criteria are established, reviewed, and approved to perform the assessment. Each document then is reviewed against the criteria and established as either applicable or nonapplicable with a respective justification. The applicability is addressed for both the DOE site and the specific facility or project.

The critical systems document contains the results of an assessment to determine which systems (hardware, personnel, and programs) are critical to safe and reliable operations of a specific facility or project. Specific criteria are established, reviewed, and approved to perform the assessment. Then each system (usually taken from a safety analysis report) is reviewed against the criteria and established as either critical or noncritical with a respective justification. 


\section{OPERATIONAL READINESS REVIEW}

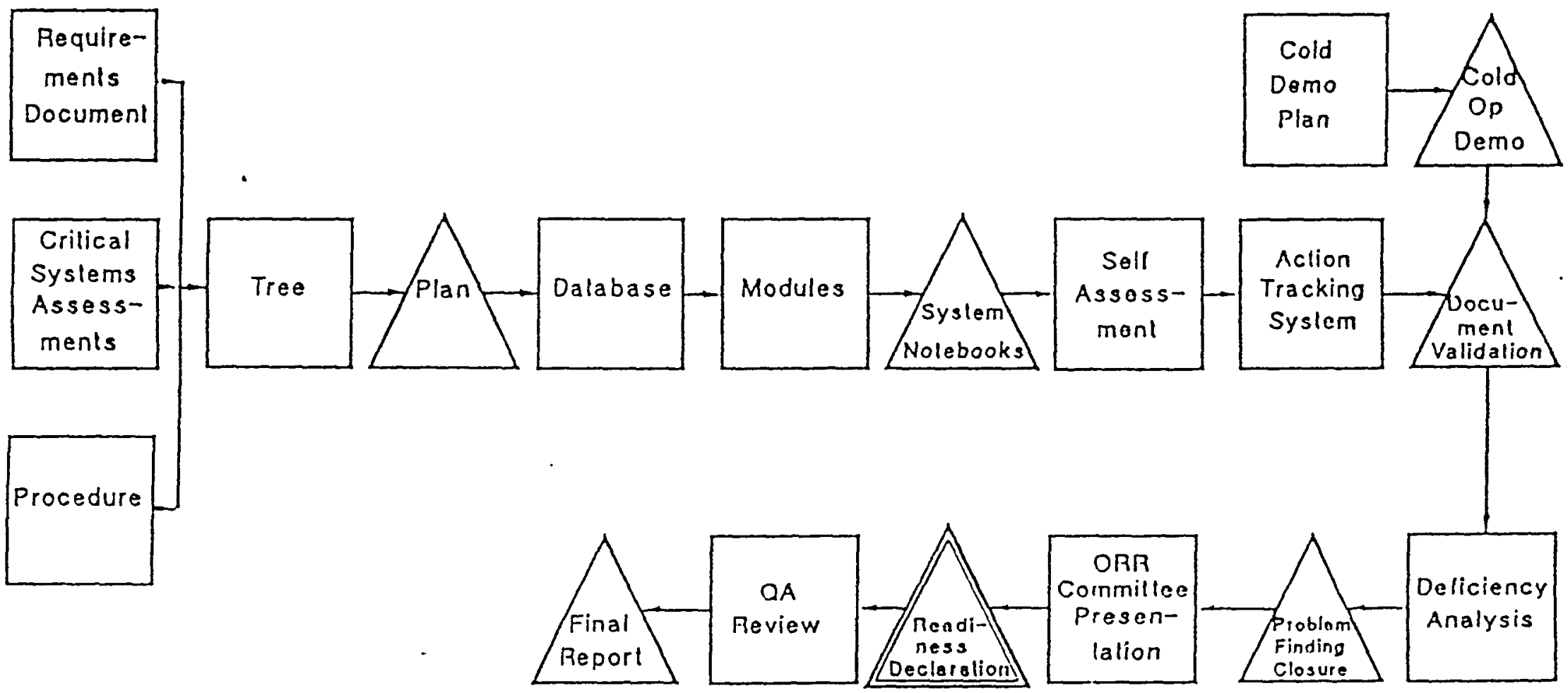

Demo $=$ Demonstration

$O P=$ Operational.

$O R R=$ Operational Readiness Review.

$Q A=$ Quality Assurance. 
The compliance decision tree is a graphic portrayal of all the critical systems. It shows which major activities under each system must be reviewed during the compliance review. The decision tree also is a graphic representation of how the following customized database will appear.

The review plan and procedures using the previous documents describe the entire review process including purpose, scope, organization, responsibilities, schedules, and success criteria. The plan is reviewed formally and approved by the appropriate organizations including the DOE field office.

The second phase, "Assessment," includes the modification of the existing RCS database, the preparation of the review checklists, the conduct of the compliance assessment by the line organizations, the initiation of an action tracking system from the existing RCS, the conduct of a document validation, the performance of a deficiency analysis, and the preparation of a plan and a critique plan for the conduct of a preoperational checkout.

The modification of the RCS database consists of extracting the specific requirements from the applicable regulatory and institutional documents as indicated in the requirements document, adding them to the existing requirements, and sorting them into the set major activities by critical system within the system.

The critical system checklists are produced in two phases. Not all of the requirements will be applicable to a specific facility or project even though the document is deemed applicable. Therefore, the checklists are printed in modules, and a final applicability assessment is conducted with justifications for nonapplicability. This further concentrates the requirements for a specific facility or project to the exact requirements that must be assessed for compliance. System notebooks then are printed by critical system with provisions for compliance documentation to be indicated for the each requirement within that system.

The actual compliance assessment is performed by transmitting the system notebooks to the line organizations, providing them with assistance as required, and requesting them to identify all available compliance documentation for the appropriate criteria by critical system. During this same period, an action tracking system is initiated from within the RCS. When the system notebooks have been completed, a document validation is conducted on a random sampling basis by an independent organization. Once all compliance information has been entered into the RCS, the actual state of compliance can be assessed and desired future compliance can be tracked. Also at this stage, external agency audit findings can be entered and tracked in the system. Further, resource and funding allocations can be identified and schedules can be prepared. If desired, the risk of noncompliance can be assessed.

A deficiency analysis is performed by collecting all noncritical deficiencies (e.g., corrective actions from nonconformance reports, work orders, preventive maintenance tasks, procurement deviations, design modifications, calibrations, corrective actions from unusual occurrences or off-normal conditions, corrective actions identified from audits or appraisals, and nonessential open items) and assessing whether or not the total of all or a group of deficiencies against a particular critical system 
should be considered a finding. This step is accomplished because a large number of deficiencies or nonessential open items can be perceived as a lack of preparation for operational readiness.

A cold operational demonstration is conducted to ensure that the dynamics of a particular system work as designed in a total system. This step is a physical performance of a proposed operation including the use of all required facilities, personnel, and procedures through an approved plan but without the use of hazardous or radioactive materials. The demonstration also shall include performance of the proper response for simulated off-normal conditions. This step is not necessary if the RCS is being used for compliance assessment only. A plan and procedures is prepared for the demonstration. A critique plan also is prepared with a subsequent critique report following the performance of the demonstration.

The third phase is the closure of all findings from the various assessments, both internal and external. This is accomplished through both electronic and physical records within the RCS.

The fourth phase is the announcement of a desired state of compliance or readiness.

The last phase is the preparation of a final report summarizing all findings and corrective actions, identification of future plans, a detailed description of the assessment process used, and the final results. This phase also includes a final quality check and archival of all records.

\section{DISCUSSION}

The RCS is a tried and proven system. In addition, the FMEF/RPSF has been used previously or currently is supporting other DOE applications and projects with positive results. Currently, it is being used for: the ORR of the TRUPACT Loading Facility at the DOE Rocky Flats Plant, Idaho Falls, Idaho; the ORR of the Supercompactor and Repackaging Facility, also at the Rocky Flats Plant; the establishment of regulatory objectives for the DOE-HQ/EM Site Roadmaps; and the evaluation and acceptance of ORRs for DOE-HQ/EM (currently three facilities at the Savannah River Plant: the Defense Waste Production Facility, In-Tank Precipitation Facility, and 1-H Evaporator). This system al so was used for Operational Readiness Review of the DOE Waste Isolation Pilot Plant (WIPP).

The following advantages and their inherent cost savings are the result of using RCS for a project.

- Provides a means to better protect personal and corporate liability.

- Provides objective, documented evidence of compliance by regulatory document, subject, or critical system on an individual requirement basis, thereby reducing future manpower requirements for the preparation of various audits and reviews by external agencies. 
- Aids in obtaining required funding for specific compliance tasks since the exact state of desired compliance can be assessed based on resource and funding availabilities. More simply, aids in determining what state of compliance the customer or custodian is willing to accept.

- Provides preliminary, integrated, concise information for project documents.

- Aids in alleviating retrofits by establishing and obtaining customer approval of all project requirements at the beginning of the various project phases rather than during or after.

- Provides documented traceable compliance evidence throughout the project Tife.

- Provides accurate, traceable information for all implementing documents and procedures.

- Provides consistent systems and records configuration from conceptual through operations phases.

- Provides for an accelerated acceptance process and ORR.

- Enhances the ability to respond to regulatory audits and appraisals.

- Provides greater visibility and impacts of future regulatory requirements.

\section{CONCLUSION}

The RCS and the database developed for FMEF/RPSF critical systems were beneficial to the regulatory compliance of the RPSF. The RCS is a key tool for the technical experts in ensuring that an important requirement has not been overlooked in assessing the operational readiness of the facility. These requirements need to be known in the beginning of the project, not during construction or startup when identified requirements necessitate retrofits, subsequent delays, and cost overruns.

\section{ACKNOWLEDGEMENTS}

David Nearing, General Manager of the WASTREN, Inc., Hanford Division, and the WASTREN, Inc., staff are acknowledged for providing information on the Integrated Project Control Regulatory Compliance System and for their input and review.

Frank Moore and John Williams are acknowledged for their valuable input and reviews.

\section{REFERENCES}

DOE, 1986, Safety of Nuclear Facilities, DOE Order 5480.5, U.S. Department of Energy, Washington, D.C. 